\title{
SPECIFIC NATURE OF THE STATUS OF A EUROPEAN UNION OFFICIAL COMPARED TO NATIONAL OFFICIALS
}

\author{
BARTLOMIEJ JAWORSKI*
}

\section{INTRODUCTION}

The paper operates on the premise that EU administration officials work in a very particular manner due to the specific nature of the international organization they are employed. In contrast, national officials of EU Member States work on different tasks, their employment is organized in different ways, and their career paths are shaped differently. The European Union differs from other organizations not only in its fundamental values, but also in the structure of its bodies. They form an interconnected system tasked with fulfilling the obligations of their organization, which serves to implement the fundamental values of the EU. Regardless of the level on which administration operates (be it national, or public national, serving state-level organizations other than the country, international or supranational), its aim should be to perform effectively and efficiently. The effectiveness of the performance of administration directly affects the performance of the organization appointing the officials that form said administration. Similarly, the European Union, whose primary aim is efficiency and success of the integration process, holds professional and robust administration in high regard. It acknowledges that without it, the main objectives of the EU could never be completely fulfilled. The provisions of the treaties formed by politicians at the top of the EU hierarchy, as well as other decisions made by people managing particular EU institutions, have to be properly implemented and applied in each Member State. Thus, the different characteristics of the work performed by EU officials and, as a result, their different status, are a consequence of operating within an extremely complex system consisting of many organizational units comprising EU organizations. The system operates based on specific criteria and values, the most important of which should be the well-being of citizens and the best interests of the European Union. As a consequence, it is a strict condition for EU administration officials to be impartial in the performance of their duties, and not to make judgments based on their nationality or political alignments ${ }^{1}$. Their only concern should be the

DOI: $10.1515 /$ wrlae-2015-0039

* PhD candidate in the field of law, University of Wrocław, Faculty of Law, Administration and Economics, the Department of Administrative Law, barłomiej.jaworski@uwr.edu.pl. 
performance of the organization they work for. This organization should be the only entity establishing an official's tasks and the manner in which they are fulfilled. Hence, the objective of this paper is to provide a general description of an official occupying a position within EU administration. It will specifically focus on the distinctive features of their status. It will also concentrate on a description of the civil service system in European Union structures as compared to systems used in particular Member States. The paper will argue for the validity of a distinct "EU administration official" category, while acknowledging that their practices are rooted in the experience of administration officials from EU Member States.

\section{EUROPEAN OfFICIAL, EU OFFICIAL AND NATIONAL OFFICIAL}

At the beginning of an analysis of a European administration official's status it is worth mentioning that every official working in the European Union, regardless of whether he is an international, national or local official, should be called an EU official. That name was adopted after the Treaty of Lisbon entered into force on 1 December $2009^{2}$. The Treaty abolished the theory of a European Union based on three pillars ${ }^{3}$. Thus, since the Treaty that reformed the founding Treaties entered into force in 2011, the "of the European Union" component can be found in the majority of names of institutions and bodies (as a result the name "official of the European Union" replaced "official of the European Communities"). Hence, we can assume that every official that works in one of the current 28 Member States is an official of the European Union. The reason for that is the obligation to follow European law and the acquis communautaire which is placed upon each EU administration official. This premise reinforces the continuity of the process of Europeanization of public authority. This process has a constitutional dimension. It uses the British concept of the rule of law (French: préémince, German: Herrschaft des Rechts) that solves issues with jurisdictional boundaries and decisions in a dynamic legal community. Poland uses the continental concept of state of law (German: Rechtsstaat). The same aim rule of law - is achieved via Article 2 of the Constitution of the Republic of Poland ${ }^{4}$. This key principle works as a guideline for EU officials on how to build a European administrative space ${ }^{5}$. It was additionally confirmed in the provisions of Article 4 section 3 of the Treaty on European Union ${ }^{6}$. It states that Member States should cooperate loyally with one another. This provision is a part of the broader policy of rule of law that contributes significantly to the process of Europeanization of public affairs. However, such a broad definition of an EU official would not benefit this analysis. Hence, the

\footnotetext{
${ }^{1}$ M Corner, The European Union: An Introduction (London 2014) 126.

${ }^{2}$ Treaty of Lisbon amending the Treaty on European Union and the Treaty establishing the European Community [2007] OJ C 306

${ }^{3}$ P S R F Mathijsen, A guide to European Union law: as amended by the Treaty of Lisbon (London 2010) 19.

${ }^{4}$ The Constitution of the Republic of Poland [1997] Journal of Laws no 78, item 483.

${ }^{5} \mathrm{~J}$ Supernat, 'Europejska przestrzeń administracyjna (zarys problematyki)' in Z Janku, Z Leoński, M Szewczyk, M Waligórski, K Wojtczak (eds) Europeizacja polskiego prawa administracyjnego (Wrocław 2005) 78-86.

${ }^{6} \mathrm{~N}$ Nugent, The Government and Politics of the European Union (Durham 2006).
} 
concept of EU official will be defined in a narrower manner - as an official directly employed by a European Union institution. It seems especially important to highlight the specific position of an EU official that works directly for the European Union and operates as part of its complex administrative structure. Only those EU officials employed by European Union institutions have a direct impact on their duties. They also draw up guidelines for national officials regarding the EU law that must be followed in each Member State individually and throughout the European community as a whole. This responsibility gives EU officials a kind of superiority and makes their status absolutely unique in contrast to all other officials in the European Union. Thus, EU officials should adjust their worldviews to the functioning of EU administration. In order to fully grasp fundamental European ideas they should at least partially renounce their (or their country's) vested interests in favour of the interests of the European Union that are common to all Member States. It would be optimal if, according to the principle of loyalty to EU and other Member States, every EU official performed his office responsibly toward the local community, their homeland, and the broader European Union community. One should also define the concept of a European official broadly, to include countries lying outside the borders of the European Union. In other words, this term will include officials of countries belonging to the continent of Europe, but not to the European Union. It will also encompass officials of all international organizations that have European countries as their members, but their seat need not be located in Europe. Hence, a European official shall mean both a national official of a European country and an official of the European Union, which is located in Europe. It is important to define the terms used in the article, and it is sufficient to define them as we have above without further detail, because of the concise nature of this paper.

Another matter is to define what a national official is and to prove the distinctness of this designation from the status of the previously described EU official. Despite the fact that both are equally required to follow and operate within the provisions of EU law, there are significant differences in their respective statuses. There is an intriguing tendency to use the title "praetor" ${ }^{7}$ to refer to an official - both national and EU one. This is a reference to Roman praetors and the treatment of one's office as a duty according to the following principle: onus est honos qui sustinet rem publicam - "The duty is the honour that holds a State". It differentiates between an EU official, i.e. "European praetor" and a national official, i.e. "national praetor". The reason for using that name is to emphasize the fundamental obligation that is incumbent upon every official, i.e. the duty to perform the tasks of the organization in which they serve. At this point, the definitions of a national official and an EU official intersect with each other. It serves as confirmation of the previously mentioned convention that every official working within a European Union Member State territory should be called an EU official, since each of them has to equally follow and work within the provisions of European law (including EU law). However, the naming convention adopted in this article

\footnotetext{
${ }^{7}$ E Ura, 'Forum Europeum' in Z Brodecki (ed) Europa Urzędników (Warszawa 2009) 3037.
} 
makes it possible to differentiate between national officials and EU officials, which has already been discussed. It emphasizes their partially different status codified in European law (international) or Member States' laws. Further in this paper, while acknowledging the differences between a Member State national official and an official employed by the European Union, the names for each type of official will be used consistently: national official for an official of an EU Member State and EU official for an official employed by an institution of the European Union.

\section{The SPECIfICITy OF The Status OF A EUROPEAN UNION OFFICIAL COMPARED TO NATIONAL OFFICIALS}

After having defined an EU official and a national official, it is possible to move on to describing the status of an EU official, assuming it is different from the status of a national one. A comparative analysis of EU administration with the officials that form it and national administration and its respective officials shows that there are numerous similarities between their statuses. They stem from the pragmatism that favours employing universal principles which operate equally well at both the state level and international administration. The experience gained by the Member States has enabled the formation of an efficient mechanism for Europe-wide administration. The well-being of the EU supersedes the interests of individual states; instead of national officials, EU ones appear; EU institutions replace the bodies of the state; instead of government-issued legal acts there are regulations or directives issued by European Union institutions, etc. The current system of a corps-type employment organization for EU officials gives them the stable status of being a member of the EU officials' corps, which offers many benefits and privileges. However, this system was not in place at the beginnings of the European Union's formation. Some authors ${ }^{8}$ claim that this system for the organization of employment was even part of the first international European institutions from the fifties. That statement is not true. While the treaties establishing the first organizations did contribute to the current system of employment in EU institutions, a lot of time was needed until the provisions that regulate the legal status of EU officials were drawn up. Part of this process was related to treaties that established, merged or reshaped the various European institutions. The current system could only emerge after those entered into force. At the very beginning of the emergence of European Communities' structures, a tendency could be observed not to employ officials for an indefinite period of time, which would have been the first step towards building a corps-based system of employment. The most common form of employment was a contract for a specified period of time. The probable reason for that was the fear of Member States of the first international organizations that they would not survive in the difficult post-war period and would have to be dissolved. In that case, the Member States would have been responsible for employing those officials on a permanent work contract. Another important characteristic of that period,

\footnotetext{
${ }^{8}$ A Dębicka, M Dębicki, M Dmochowski, 'Status prawny urzędników Unii Europejskiej' 2005 (9) Służba Cywilna 71.
} 
aside from short-term employment, was the lack of commonly-accepted rules of employment for each of the institutions that belonged to the organizations emerging at the time. Each of them drew up its rules for recruiting officials separately, including salaries, privileges, allowances and other benefits stemming from performing service for a particular organization. This state lasted until the end of the 1960s. Currently, however, one can speak of an EU community system of employment ${ }^{9}$ shaped by years of experience in performing tasks at the international level. That gives one basis for analysing the position of the EU official who, the same as the national one, is a part of a specialized administrative corps working under specific provisions of European secondary legislation. ${ }^{10}$ It serves a similar purpose in the political system of the EU as does legislation in the legal system of each Member State $^{11}$. Additionally, as was mentioned in the introduction, the EU political system (sometimes likened to the system of an individual state, which is a slight exaggeration) requires strengthening of the element of intent, just as the national system and state-level administration does. That is due to the farreaching political and legal consequences of its actions on its members and the general scale of its operations ${ }^{12}$. An efficient and effective administration should have a proper institutional dimension that requires its members to be professional, honest and well-versed in European law ${ }^{13}$. EU officials should strive for the most effective way of performing their duties while remaining compliant with the constraints of the letter of the law and professional integrity. They should not be subjected to any external influences that could encourage them to make decisions based on something other than the official's expertise and his professional experience, achieved during long years of service in the organization.

The aforementioned similarities in the status of an EU and national official are due to the fact that the EU administration, just as the European Union as a whole, was built on a compromise between different solutions implemented in each Member State. Only later were several specific changes added as an expansion of the original ideas in the Treaties. Thus, an inherent characteristic of national officials is that they have as much power as has been granted to them. That idea is based on the concept of hierarchical delegation of governing power to employees of the public administration. Their role is to ensure the efficient operation of the mechanism of constitutional principles and administrative law in everyday practice ${ }^{14}$. Just as national administration ensures proper governance at the state level, the objective of the EU administration is set out under Article 211 of the Treaty of Rome establishing the European Economic Community: "In order to ensure the proper

\footnotetext{
9 J-L Quermonne, Le système politique de l'Union europèenne (Paris 1998) 33-59.

${ }^{10} \mathrm{~J}$ Galster, C Mik, Podstawy europejskiego prawa wspólnotowego (Toruń 1998) 145.

11 Quermonne (n 9) 60-80.

12 J Łętowski, Prawo administracyjne dla każdego (Warszawa 1995) 9-12.

${ }^{13}$ European Personnel Selection Office, 'Careers at the EU institutions' (Luxemburg 2003) $2 \mathrm{ff}$.

${ }^{14}$ A Kroeger, 'Służba cywilna w demokratycznym społeczeństwie' in J Jacki (ed) Stużba cywilna a etyka $w$ życiu publicznym: materiały z konferencji zorganizowanej z okazji 6-lecia Krajowej Szkoły Administracji Publicznej w dniach 14-15 marca 1996 r. (Warszawa 1996) 40-41.
} 
functioning and development of the common market, the Commission shall: ensure that the provisions of [...] Treaty and the measures taken by the institutions pursuant thereto are applied"15. Thus the EU administration holds similar responsibilities towards the EU as national administration does towards the state that established it. The European Commission is the main representative of the European Union's interests. Its professional corps of officials works to secure European interests, make political decisions and boost the efficiency of the European integration process ${ }^{16}$. The national officials of Member States are obligated to perform their duties in accordance with the constitution of the state. At the EU level, with regard to EU officials this obligation is grounded in the founding treaties of the European Union. In more practical terms, the aforementioned duty to serve the organization (the state or the EU) that appointed a particular official means the obligation to remain neutral politically and nationally, and to fully contribute to the organization one serves. This obligation is stated in Article 4 section 3 of the Treaty on European Union ${ }^{17}$. At the Member States level the same obligation is set out in their respective constitutions as they relate to national administration. The neutrality principle has its roots in the separation of two spheres: the public and the private ${ }^{18}$. The public interest must take precedence over any individual interest. The public sphere must remain free from any external influences and pressure on political pursuits, since they are relatively changeable and seasonal. This fundamental rule, as was mentioned before, is common to both the administration of the Member States and the European Union as a whole. Failure to observe this principle can have tragic consequences, as we could see in the 1980s when corruption scandals involving EU politicians came to light. The president of the European Commission at this time was Jacques Santer. Aside from the corruption, other irregularities were also uncovered. All of them were related to the performance of duties in a dishonest manner and placing individual interest before that of the organization. Those events demonstrate how important it is to separate the public interest from the private and, as a consequence, politics from administration ${ }^{19}$. It is crucial and essentially mandatory to maintain complete apoliticism on the part of officials, as well as to restrict the influence politicians have on appointments to administrative positions. Politics and administration should operate parallel to each other in the public sphere. Although naturally connected and continually influencing one another, they should, by their nature, remain separated, with different logics that motivate them and different sources of legitimacy ${ }^{20}$. Keeping in mind the aforementioned separation of politics and administration, it can be argued that politics is based on the trust of the public as expressed in free and democratic

\footnotetext{
${ }^{15}$ Consolidated version of the Treaty on European Union and of the Treaty establishing the European Community OJ C 325.

16 J-L Quermonne (ed), L'Union européenne en quête d'institutions légitimeset efficaces (Rapport du groupe de réflexion sur la réforme de institutions européennes) (Paris 1999) 4143; See also: M Cini, N Perez-Solorzano Borragan, European Union Politics (Oxford 2013).

${ }^{17}$ Consolidated versions of the Treaty on European Union, OJ C 202

${ }^{18}$ Kroeger (n 14) 41-42.

${ }^{19}$ D Długosz, 'Neutralność polityczna służby cywilnej' in I Szymanowska-Woźniak (comp.) Stużba cywilna - wybrane zagadnienia (Warszawa 2000) $3 \mathrm{ff}$.

${ }^{20} \mathrm{R}$ Herbut, 'Administracja publiczna - modele, funkcje i struktura' in A Ferens, I Macek (eds) Administracja i polityka. Wprowadzenie (Wrocław 1999) 39.
} 
elections, while administration is based on the professional merit and expertise of officials who are assessed in an open and competitive recruitment process, governed by legislation on recruitment of officials for certain positions. Thus, the EU administration is a collection of apolitical professionals, as they are the only ones who fulfil the criteria of the European Union treaties. Although a prohibition on membership in political parties in relation to EU officials is not explicitly stated in any document, it can be inferred from the general principles in the Staff Regulations of Officials of the European Union ${ }^{21}$. According to this document, an official should be impartial and work on behalf of the interests of the European Union in all circumstances. His decisions must not be influenced by pressure from any institutions, governments or organizations. An EU official must also not engage in any activity that would negatively affect the reputation and dignity of the EU institution he represents. The Staff regulations also introduce the incompatibility principle, which states that in the case of an EU official being chosen for any public office, his function as an EU official is suspended for the entire time of service in that office ${ }^{22}$. It is essential that the recruitment process for public administration, both at the state level and the EU level, be performed in a competitive and open manner. Harmonized and publicized criteria and conditions of pre-selection are crucial. Otherwise, it might lead to a concentration of power in the hands of a particular group that holds public positions unlawfully and continuously ${ }^{23}$. An important similarity between EU and national officials is their tendency to form proper ethical and professional attitudes among officials by developing the individual responsibility of each official. In other words, they try to depart from making collective decisions. Moreover, what is commonly seen as the essence of the status of an official, both of the Member States and the European Union as a whole, are tasked with providing their officials with a proper level of employment protection, stability and conditions, as well as clearly defined duties and rights ${ }^{24}$.

\section{The Career And Position System - THE Administration SYSTEMS IN THE EUROPEAN UNION MEMBER STATES}

The analogy between the status of an EU official and a national official partially depends on the administration system adopted in a particular Member State. Thus, it is important to describe the two basic systems of administration that are currently in use in the Member States of the European Union. This issue is closely related to the concept of civil service, since the system of administration, understood as the fundamental operational model of administration, means a certain type of civil service that can be characterized with specific systemic regulations. According to the principle

\footnotetext{
${ }^{21}$ Staff Regulations of Officials and the Conditions of Employment of Other Servants of the European Economic Community and the European Atomic Energy Community, Title II: Rights and obligations of officials, OJ L45

${ }^{22}$ ibid, Article 11.

${ }^{23}$ B Kudrycka, Neutralność polityczna urzędników (Warszawa 1998) 125.

${ }^{24} \mathrm{~S}$ Goodings, 'Konieczność tworzenia służby cywilnej na zasadach etyki zawodowej' in Jacki (n 14) 116 ff.
} 
of subsidiarity, the Member States can exercise their sovereignty by inter alia independently shaping their systems of administration, including the structures of their civil service. The diversity of ideas in this field results from distinct traditions, cultures and histories. This can be seen, for example, in the lack of positive legislation on officials that would harmonize the principles of civil service operation in all Member States (although we may already observe the process of Europeanization of administrative law. Some procedural elements, however, remain specific to particular Member States ${ }^{25}$ ). Thus, the term "civil service" is used in many states to denote the legal situation of employees (officials) working in public bodies and institutions, as opposed to service in military bodies. The civil service is regulated by special legal provisions (labour regulations), usually different from the general labour law. They are based on specific legislation ${ }^{26}$. A sine qua non condition of public service is performing tasks assigned to the national administration based on the transfer of power to enforce political decisions to the administrative level ${ }^{27}$. The aforementioned definition of civil service refers to the Polish understanding of the term. In other Member States of the European Union it is defined in different ways. In France, Spain, the Netherlands, Ireland and Sweden, civil service encompasses all public employees who are an integral part of the state management system. In the remaining Member States, including Austria, Germany, the United Kingdom, Denmark and Italy, civil service refers only to the so-called core part of public administration. Only the employees of the public management and administrative sphere, and those exercising state privileges (police, customs service) are included. In all EU Member States there are special legal regulations that define the status of a civil service employee ${ }^{28}$. In most EU states those regulations are included in the constitution, and the details of how the civil service operates are regulated by specific legal and executive acts. By principle there also exists a distinction between appointed civil servants and employees working under an employment contract. A good example of that distinction is Germany, where only $30 \%$ of six million public sector employees are appointed civil servants ${ }^{29}$. The civil service, understood as in the definition above, is a part of state authority and the public sphere. Its form is dependent on the institutional and administrative solutions stipulated in the law.

Those different solutions, as mentioned before, form a certain type of civil service with specific systemic regulations. Together they comprise one of the two administration systems in the EU Member States - a career system or a position system. The choice of a specific system, as well as establishing a civil service in a suitable form for a specific country, is related to the history of particular states and their political system as a whole. In countries where public administration has traditionally been the main guarantee of the state's

\footnotetext{
${ }^{25}$ Z Niewiadomski, 'Kodeks Dobrej Administracji a polska procedura administracyjna' in J Łukasiewicz (ed), Jakość administracji publicznej. Międzynarodowa konferencja naukowa Cedzyna k. Kielc, 24-26 września 2004 r. (Rzeszów 2004) 22-49.

${ }^{26}$ Nowa encyklopedia powszechna PWN, Warszawa 2003, entry: 'Służba cywilna”.

${ }^{27}$ E Best, Understanding EU decision-making (New York 2016).

${ }^{28}$ G Rydlewski, Stużba cywilna $w$ Polsce. Przeglad rozważań na tle doświadczeń innych państw i podstawowe akty prawne (Warszawa 2001) 23-24.

${ }^{29}$ L Sinkowska, Status prawny członka korpusu służby cywilnej (Torun 2002) $110 \mathrm{ff}$.
} 
stability, for example, in France ${ }^{30}$, the career system was chosen. In contrast, relatively stable countries without many political tensions, such as Great Britain, were more likely to develop a position system ${ }^{31}$. Those characteristics are purely theoretical, since no country currently represents one of those systems in its entirety. They tend to make their public administration more flexible by combining the career and position systems, which helps them adjust to the challenges of contemporary reality ${ }^{32}$. Let us briefly describe the career system, sometimes also called the closed system. It is typical for this system to divide the civil service into levels, ranks and corps. New employees are usually recruited for the lowest positions. They are promoted based on a nomination or, sometimes, internal competition. The employee's authority is strictly connected to their position (rank). This system is typical for continental European mentalities - mainly French and German - that holds the law, hierarchy, administrative procedures and separation of public administration from the private sector in high regard. Since the public sector has a different purpose, it needs to develop different criteria for recruitment, assessment and accounting for the tasks performed by its employees. The weak points of this system are: low motivation to improve the quality of work because of a strict remuneration system and lack of competition, high costs of civil service because of the guarantee of employment and remuneration, and lack of adjustment to the principle of free movement of workers which since the beginning was fundamental for creating immunities and privileges for officials working outside their homeland in European institutions. This system can be found, among others, in Austria, Belgium, France, Greece, Spain, Ireland, Luxemburg, Germany, and Portugal ${ }^{33}$, i.e. in the countries characterized by the so-called restricted concept of public service, where the term only refers to the so-called core part of public administration. The other administration system present in contemporary Europe is the position system, sometimes also called the open system. Its distinctive quality is recruitment for specific positions, usually in open competitions (especially for higher ranking positions). A common form of employment is by contract. The basis for assessment of an employee is their professional achievements, not membership in a particular group of officials. Employees also get promoted based on their achievements. There is no place for hierarchy in this system; what matters is the results of the employee's activities. There is a closer connection between administration and citizens, as well as between the public and private sector. This can be seen in the free movement of workers between the sectors, and in similar assessment and recruitment criteria. Instead of formal qualifications, managerial skills are the most valued ${ }^{34}$. This system is mostly typical for Anglo-Saxon and Scandinavian countries. It can be found in Denmark, Finland, the Netherlands, Sweden, the United Kingdom and

\footnotetext{
${ }^{30}$ P Sarnecki, Ustroje konstytucyjne państw współczesnych (Kraków 2003) 252 ff.

${ }^{31}$ D Długosz, 'Służba cywilna - jaki system dla Polski' 1998 (6) Res Publica Nowa 32 ff.

${ }^{32}$ L Rouban, 'La réforme de l'appareil d'État' in W Wright, S. Cesse (eds) La recomposition de l'État en Europe

(Paris 1996) $138 \mathrm{ff}$.

33 A Auer, Ch Demmke, R Polet, Civil Services in the Europe of Fifteen (Maastricht 1996) 139.

${ }^{34}$ Mountfield, 'Brytyjski model służby cywilnej w procesie zmian', in Jacki (n 14) 54 ff.
} 
Italy $^{35}$. The drawbacks of this system include the weak connection officials have to institutions and their work, high susceptibility to external factors (not always aligned with the public interest), as well as low efficiency in longterm endeavours and those that require maintaining state secrecy. Nevertheless, administration functioning under this system can be characterized by flexibility and resistance to changing external conditions, which better contributes to building a professional corps of officials.

The system of administration adopted in the first European Communities, which later evolved into the current European Union, was based on the career system. This choice was highly influenced by the two largest of the initial six members of the Communities, namely France and Germany. They were accustomed to the career system which treats celebrating administrative procedures as a norm. Recruitment was used almost only in order to fill lower positions in the hierarchy. If possible, recruitment was avoided at all costs, only to happen when reassignment, promotion or internal competition could not lead to selection of an official for a position. The main drawback of implementing this system in a developing supranational European organization, which subsequently evolved into today's European Union, was the significant restriction on flexibility in adjusting to new challenges it had to face. The career system needed more flexibility and had to be able to overcome new challenges that the EU could no longer ignore if it wanted to survive $^{36}$. These included budgetary restrictions, higher demands from society, greater efficiency and productivity expectations, and growing standards of individuals who decided to seek a career in EU structures ${ }^{37}$. The direction of these changes was first formulated in Reforming the Commission. $A$ White Paper, published in March 2000. ${ }^{38}$ Along with The European Code of Good Administrative Behaviour, from $2000^{39}$ and building a culture of European civil service based on the Code of Ethics, this led in 2003 to a partial departure from the strict career regime, modelled after the French system. Emphasis was placed on efficiency in spending as well as the effective use of human resources, according to the principles of transparency, responsibility, a pro-citizen approach and financial efficiency (value for money). Moreover, employee mobility across and within institutions was increased. Within three years of reforms after the White Paper was published in March 2000, positive changes could be observed in the process of modernizing EU administration $^{40}$. An important part of these reforms was the introduction of a unified system of recruitment and competitions for higher-ranking positions. Before the reforms, they were filled with officials promoted after their period of employment ended. Those changes made the previous career system more flexible ${ }^{41}$. A competition-based recruitment system where information about vacancies is always publicly posted is definitely a good step towards employing effective officials with the highest qualifications as

\footnotetext{
${ }^{35}$ Auer, Demmke, Polet (n 33) 139.

${ }^{36}$ G Friedman, Flashpoints: The Emerging Crisis in Europe (New York 2015).

37 J Czaputowicz, 'Służba cywilna w instytucjach Unii Europejskiej'(2003) 6 Służba Cywilna 39.

${ }^{38}$ Reforming the Commission. A White Paper, COM (2000)200.

${ }^{39}$ The European Code of Good Administrative Behavior [2000] OJ L 267

${ }^{40}$ Progress Review of Reform. Communication from the Commission, COM (2003)40.

${ }^{41}$ G Chorąży, 'Reforming the Commission. A White Paper' (2000-2001) 1 Służba Cywilna $160 \mathrm{ff}$.
} 
well as impeccable professional integrity. It helps to select officials who will not require a very long time to prepare to serve in the organization, since the expertise and experience they already have will allow them to quickly assimilate into the unique EU environment and work effectively from the first months of their employment.

\section{CONCLUSION}

European Union officials, defined as only a small number of European officials employed directly at EU institutions, are officials holding a special status as compared to other officials that work for particular Member States of the European Union, id est national officials. Despite those differences, regardless of the system of administration adopted in a particular Member State of the European Union, the preceding analysis allows us to identify several analogies pertaining to the status of an EU official and a national official. Those are: the conditions regarding the duties and rights of EU officials, professional stability, protection from lobbying and political pressures, proper level of remuneration shielding from corruption, rules for disciplinary procedures, selection based on professional expertise. Those are the current standards that make organizations operate effectively, be it national or supranational. Differences that emerge are the result of the scale of a given operation, i.e. the more numerous and international a group that is more susceptible to the negative consequences of their actions, the more it will be privileged $^{42}$. Thus, the status of an EU official is, so to say, more beneficial than that of a national official when considering shorter working hours, longer vacation time and higher salaries (especially in the higher ranks of the EU hierarchy).

\section{References:}

1. Auer A., Demmke Ch., Polet R., Civil Services in the Europe of Fifteen, Maastricht 1996.

2. Best E., Understanding EU decision-making, New York 2016.

3. Brodecki Z. (ed.), Europa Urzędników, Warsaw 2009.

4. Chorąży G., Reforming the Commission. A White Paper, „Służba Cywilna" autumn-winter 2000-2001, number 1.

5. Cini M., Perez-Solorzano Borragan N., European Union Politics, Oxford 2013.

6. Corner M., The European Union: An Introduction, London 2014.

7. Czaputowicz J., Implikacje integracji z Unia Europejska dla polskiej służby cywilnej, „Służba Cywilna” 2001 number 1.

\footnotetext{
${ }^{42} \mathrm{~T}$ Mehlhausen, European Union enlargement: material interests, community norms, and anomie (London 2016).
} 
8. Czaputowicz J., Stużba cywilna w instytucjach Unii Europejskiej, „Służba Cywilna” spring-summer 2003, number 6.

9. Dębicka A., Dębicki M., Dmochowski M., Status prawny urzędników Unii Europejskiej, „Służba Cywilna” 2005, number 9.

10. Długosz D., Stużba cywilna - jaki system dla Polski, „Res Publica Nowa" 1998, number 6.

11. Ferens A., Macek I. (ed.), Administracja i polityka. Wprowadzenie, Wrocław 1999.

12. Friedman G., Flashpoints: The Emerging Crisis in Europe, New York 2015.

13. Galster J., Mik C., Podstawy europejskiego prawa wspólnotowego, Toruń 1998.

14. Jacki J. (ed.), Stużba cywilna a etyka w życiu publicznym: materiaty z konferencji zorganizowanej z okazji 6-lecia Krajowej Szkoty Administracji Publicznej w dniach 14-15 marca 1996 r., Warsaw 1996.

15. Janku Z., Leoński Z., Szewczyk M., Waligórski M., Wojtczak K. (ed.), Europeizacja polskiego prawa administracyjnego, Wrocław 2005.

16. Kudrycka B., Neutralność polityczna urzędników, Warsaw 1998.

17. Łętowski J., Prawo administracyjne dla każdego, Warsaw 1995.

18. Łukasiewicz J. (ed.), Jakość administracji publicznej. Międzynarodowa konferencja naukowa Cedzyna k. Kielc, 24-26 września 2004 r., Rzeszów 2004.

19. Mathijsen P.S.R.F., A guide to European Union law: as amended by the Treaty of Lisbon, London 2010.

20. Mehlhausen T., European Union enlargement : material interests, community norms, and anomie, London 2016.

21. Młodawa T., Wojtaszczyk K. A., Małecki M., Administracja publiczna w procesie dostosowywania do Unii Europejskiej, Warsaw 2003.

22. Nugent N., The Government and Politics of the European Union, Durham 2006.

23. Quermonne J.-L. (ed.), L'Union européenne en quête d'institutions légitimeset efficaces (Rapport du groupe de réflexion sur la réforme de institutions européennes), Paris 1999.

24. Quermonne J.-L., Le système politique de l'Union europèenne, Paris 1998.

25. Rydlewski G., Stużba cywilna w Polsce. Przeglad rozważań na tle doświadczeń innych państw i podstawowe akty prawne, Warsaw 2001.

26. Sarnecki P., Ustroje konstytucyjne państw współczesnych, Cracow 2003. 
27. Sinkowska L., Status prawny członka korpusu służby cywilnej, Toruń 2002.

28. Szymanowska-Woźniak I. (comp.), Stużba cywilna - wybrane zagadnienia, Warsaw 2000.

29. Wright W., Cesse S. (ed.), La recomposition de l'État en Europe, Paris 1996. 